\title{
東南アジアの大都市の地域構造における特色一概報
}

\section{田辺健 一}

はじめに 筆者は本年3月中旬全く突然に文 部省より4月 10 日から 7 月9日までの 90 日間 の在外研究を命ぜられ，7ケ国にわたり 13 の都 市を見る機会を得た。日程の約 3 分の 2 をホン コン・バンュック・シンガポール・ジャカル タ・カルカッタの東南アジアの都市で過した。 勿論これらの都市は筆者の全く個人的な興味か ら選定したもので患って, これらの都市で東南 アジアの都市のすべてが代表される性質のもの ではないし, その上, 準储の時間の久如と外地 滞在の未経験とに加えて, それらの地城での政 情不安などから，全く不充分な結果しか得られ なかった。しかし一応の義務としてとりあえず 概報を発表することにした。

各地で種々打世話になり，あるいは多くの熕料を提供

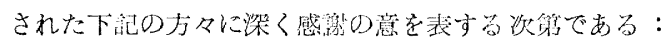
ホンコン公共事紧局 Mr. R.C. Clark, 中文大学陳正 祥教授,バンコックの City Adviser Dr.L. Sternstein, シンガポール都市瑇開発㕍長 Mr. Alan F.C. Choe, 南洋大学潘明智葙師, シンガポール大学 Dr. R. J.W. Neville 講師，インドネシア国立行政研究新 Dr. F.X. Soedjadi, Mr. I. Tjokrokusumo, および Mr. S. Danuredjo, インドネシア大学学生西层咲子, カルカッ 夕大都市圈計画局 Mr. B.C. Ganguli 局長, Mr.M.G. Kutty 次長, Joya O. Gupta 夫人, Mr. A. Bannerji。
な扔, ジャカルタの大使館およびカルカツタの総領事館 の方々の御䅧切に刘し厚く御礼果上げる。

ホンコン 行政的なホンコンは香港島のヴィ クトリア村と九竜半島の九竜市とその他の小集 落から成っているが，こ〉ではヴィクトリア市 のみをとり岁げる。香港島北部の海岸に位置 し, 幅約 $1000 \mathrm{~m}$ の埋立による平地しかなく, 街の3 分の 2 はかなり急な斜面に位置してい る。中央部の埠頭から真南に斜面を上って政府 機関が立地し，その東の海岸に陸海軍の用地が 安り, 支那人街を東と西に 2 分している。西部 の支那人街と中央埠頭との間に多くの銀行・商 社が集中し，業務中心となり，その西涪商中 心がつづく。住宅地区は，政府機関の東の斜面 に古くからの高級アパートと個人住宅とが女 り, 新しいアパートが両支那人街の南の斜面化 作られている。支那人街は汪とんど商業地区で めって, 1〜2 階が商業, 3〜4階が住居とされ， 職場と住居との水平的分離がなく, 従って香港 島での住宅地区は形の上では著しく狭い(第1図 写真 1 参照)。

バンコック メナム河 (チヤオブラヤ) の両岸 を占めるが, 左岸が主要市街地で, 海抜 $2 \mathrm{~m}$ 内

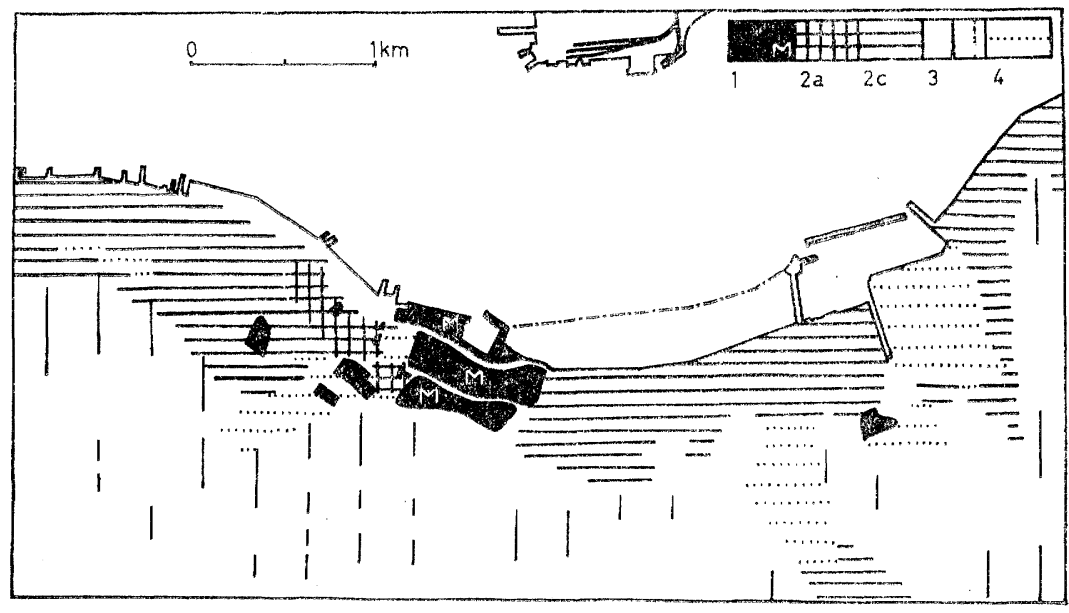

Fig. 1 Land use of Hong Kong

1: Administrative area 1 M : Military use $2 \mathrm{a}$ : Central business and shopping area 2c: Commercial area 3: Residential area 4: Green belt 
外の低平な土地に広く拡がっている。寺院が著 しく多く，極端な言い方で洔院の間を縫って 街が拡がっていると言える。西部の王城を要々 して，まわりに官朾街が要り，北に事務所街， 南に支那人街が女る。河に臨む支那人街は甫 場・倉庫・卸問屋が多く, 内側に小売中心が安 る。小売業は業種が細分されてはいるが，1街 区に同一業種が集っていることが多く，小売業 地区間での地域分化が $1 つ の$ 特徴となってい る。支那人とタイ人とが混在する地区では小壳 商店々並んで各種の小家内工場が岕る。南東部 に外国公館の集る地区があり，戦前の南街地の 外縁に当っている。支那人街は店䧼併用住宅で 岁るが，タイ人の住居保，道路に沿った併用住 宅で農村集落が取りかこまれた形をとり，低湿 で不良住宅化している。最近東部に高級住:宅地 区が形成され，新しい商店街子 $2 ， 3$ 作られて きた(第 2 図参照)。
シンガポール シンガポール皂南東部に安る 連街地の中心恃，シンガポール河左岸の官打街 と右岸河口に近い銀行街にある。左岸の政庁・ 議事堂・高等法院とその北束に続く幾つかの学 校・教会が美事な芝生をるら中央緑地带的存在 となって，市街地を東西に2 分する。右岸の銀 行街から西が China Town と呼ばれる支那人 街で, 新聞社・墑社が集中し, 卸売間屋・倉庫 などが密集する。その地区の西は港湾地区とな る。左岸の官打街の北に小売商業の中心がめる が，北東部の市街地と離れているので，北東部 の市街地飞も副中心的商業地区が形成されてい る。こ〉も大部分は支那人であるが，マレー人 イント゚人も混住している。古い住宅地区は，こ れらの市街地の背後に樹木の多い平屋の住宅群 そして散在していたが，最近ではその間岁るい はその外側に大規模なアパート群が建設されて きた。その結果，住宅地内の商店街のオーチャ

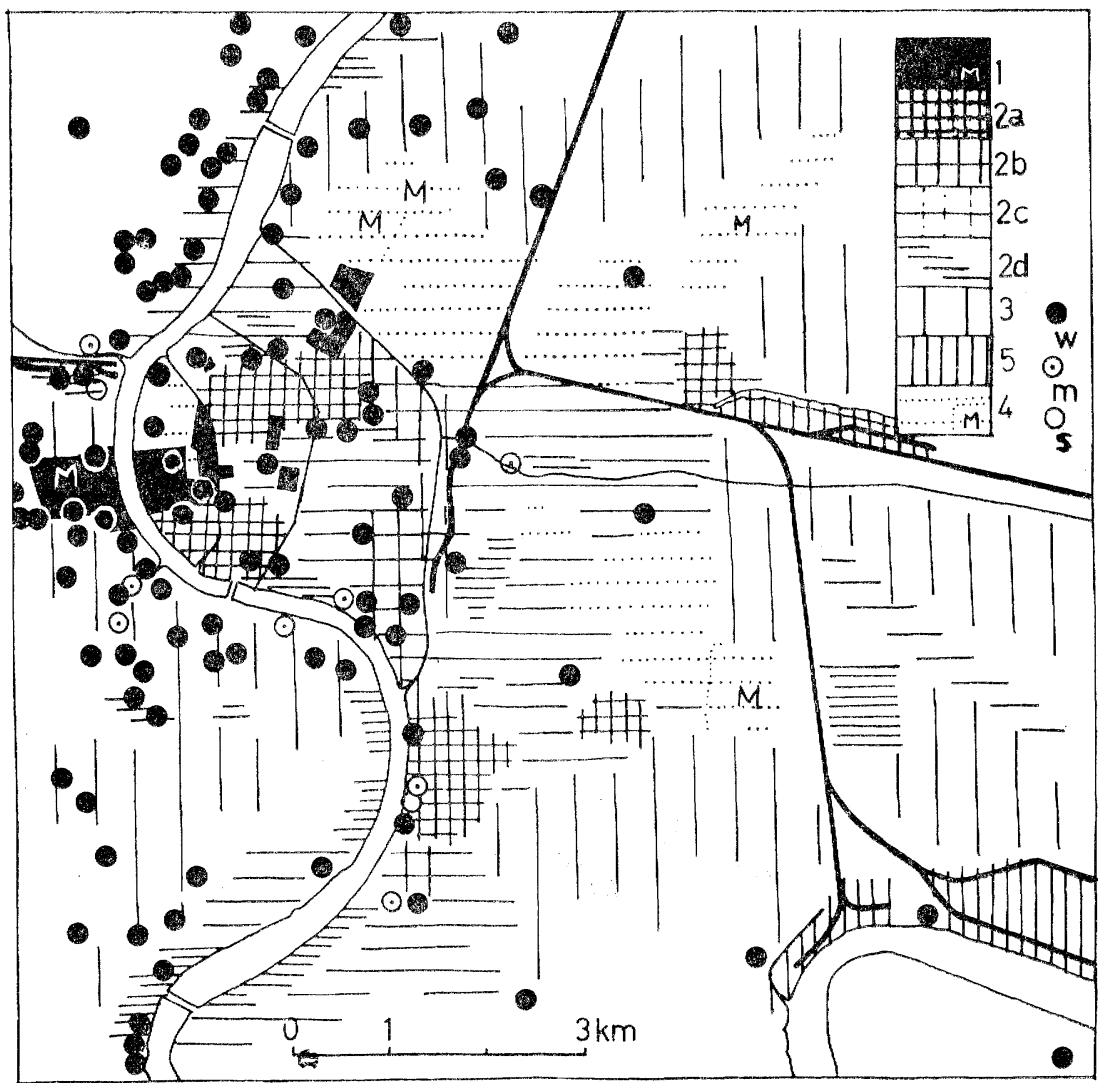

Fig. 2 Land use of Bangkok

$2 \mathrm{~b}$ : Wholesale area

5: Traffic area

$\mathrm{S}$ : Chinese shrine 2d: Industrial area

w : Wat (Thai temple)

4 M : Military field

$\mathrm{m}$ : Mosque 


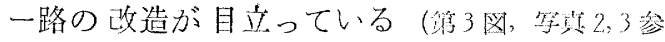
照)。

ジャカルタ 元のバタビアであるが，中央部 の独立広場を中心涫庁地区があり，その北部 に支那人街を中心とした最も古い市街地があ る。その東部が銀行街となり，中央默が女る。 その南に官庁地区との間に支那人の住宅地区が める。この住宅地と官打街との間に事務所街と 中心小売商店街が女る。官庁街の南東部纪第2 の支那人街が形成されている。官庁街の南に植 民地時代からのヨーロッパ風の緑の多い住宅地 区が拆がり，外国公館も多く法ここに位固して いるが，鼠近独立広場から南へ走る大通りに移 動している。これらの古い市街地の外側に, 外 颜環状線的な高速道路が建設され，それに伴。 た新しい住宅地区が幵成されてきた。港タンジ ョンプリオクは市街の北東方にめり，尔だ市街 地の連綂はみられない(第4図, 军真4,5参照)。
カルカッタ フーグリー河の右岸にバウー ラ, 左岸にカルカッタがあり, 両市街地を合せ て大カルカッタとなるが，左岸にのみ限って記 述する。市街地の周辺はほぼ鉄道と運河によっ て限られ，中央部に広い公園・競馬場などの緑 地があり，その北にダルホージー広場を中心に 官公庁が集中し，その周辺に銀行・商社の集。 た地区がある。北部から東部にか惊てインド人 の集中する人口稠密な市街地があり，それにと りかこ采れた形で官庁地区の東側に支那人町が 岁る。南東部技上び南部には中世風の建物の高 級住宅地がめる。南西部は港湾地区で, 東部の 鉄道抒よび北東部の運河沿いにジュート工場・ 木工場・治金工場などとともにスラムが拡がっ ている。支那人町と中央公園南東部に都市再開 発による高層建築物の建造が進められ, 北東部 の Salt Lake の干拓を中心にスラムクリアラン スの新郊外団地の建設が行なわれている(第 5

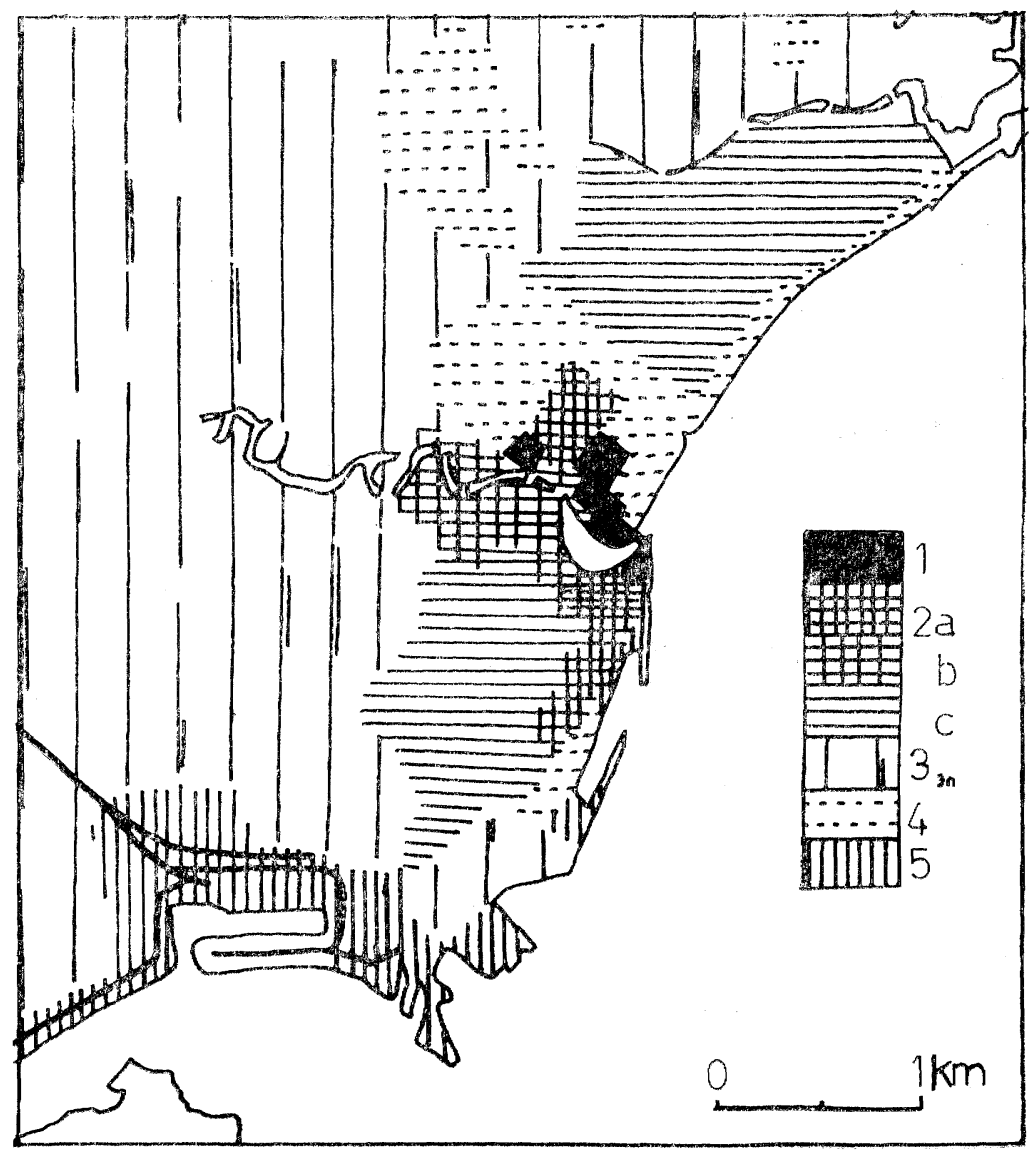

Fig. 3 Land use of Singapore

3n: New residential area 
図, 写蒖 7 参照)。

\section{結}

論

上述の5つの都市の発達過程には，それぞれ 特徵があって，一見全く䎭っているようである が，その都市構造には幾つかの共通点を見出す ことが可能である。その一つは，それぞれの地 域の中での最大の都市であり，政治・経済の中 心になっていることで岕る。第2 は人種構成 上，殆ど 100\% 支那人の街であるホンコンか ら, 75\% の シンガポール， 10\% のバンコッ ク，5\%のジャカルタ，0.1\%のカルカッタと 程度の差こそ䒚れ, 支那人の人口の占める比率 がかなり高いことで女る。第了は，バンコック を除いて，植民地をるいは植民地経営の中心と
して都市建設が行なわれたことである。これら の共通点が都市構造の上に現われている。すな わち，行政の中心である官公汀が，植民国の当 時の建築様式学完全に残して, 都心を形成し, 緑の芝生の都心公園之相俟って，一つの景観的 特徵を与えている。この行政地区に直接して銀 行街があり，その外側に商業地区が形成されて いる。商業地区では卸売商業地区がかなり広 く，中心小壳商業地区は比輁的狄い。そしてこ の商業地区が所謂支那人街 “China town” で 要って, 住居と職場の分離がなく, 著しく人口 稠密な戗街地を形成している。行政地区と率業 地区とで都心地区が形成されるので变るが，商 㘹中心よりも行政中心が敞心地区の中核をなし ている。

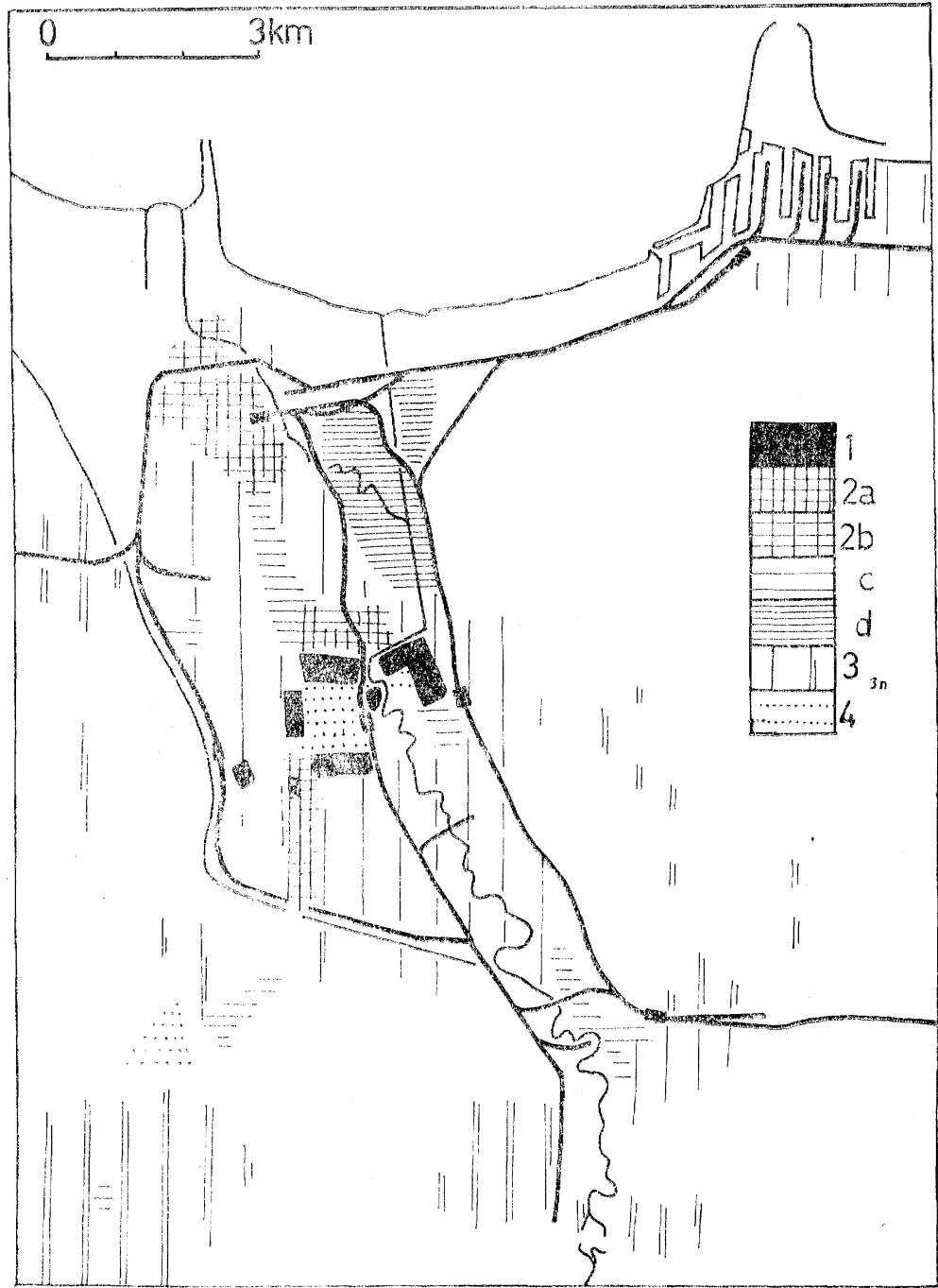

Fig. 4 Land use of Djakarta 
一方それらの外側の占める居住地区 としては, 商業地区縁辺の支那人街が 中・下級住宅地区的様相を示し，それ と対称的位置にからての外人住宅地区 が緑の多い高級住宅地区として今も残 っている。そして戦後にそれらに隣接 して新たに中・下級の住宅地区が形成 された。

したがって, 都市の地域構造として は，一応欧米扮よび日本の諸都市で認 められた，同心円構造がこれらの都市 でも認められる。しかし，住宅地区の 著しく狭いこと，行政地区の著しく広 いこと，扣よび商業地区に支那人街が 重複している点に, 都市成立の歴史的 背景と人種構成とに東南アジアの都市 としての特徴が示されている。

な扮, これらの地域構造は, 戦後, 特に最近 10 年間に, それぞれの都市の 属している政治体制と立地している地 形とに応じて，急速な変化をみせはじ めているが，矢れらについては次の機 会に発表したい。（1967.9.19受理）

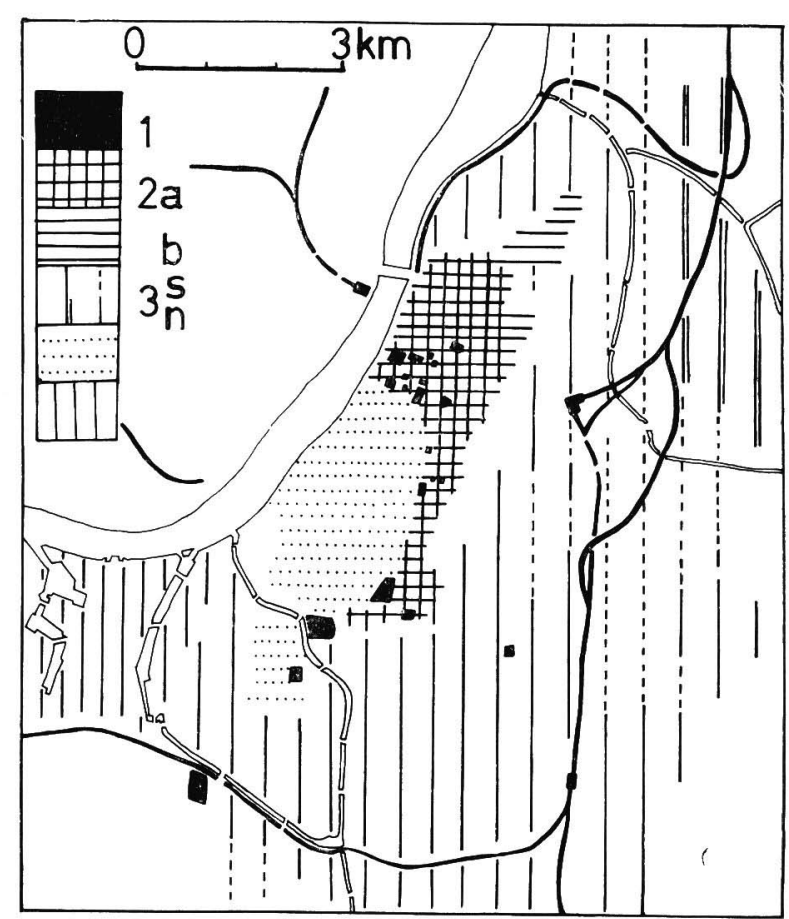

Fig. 5 Land use of Calcutta $3 \mathrm{~s}:$ Slum

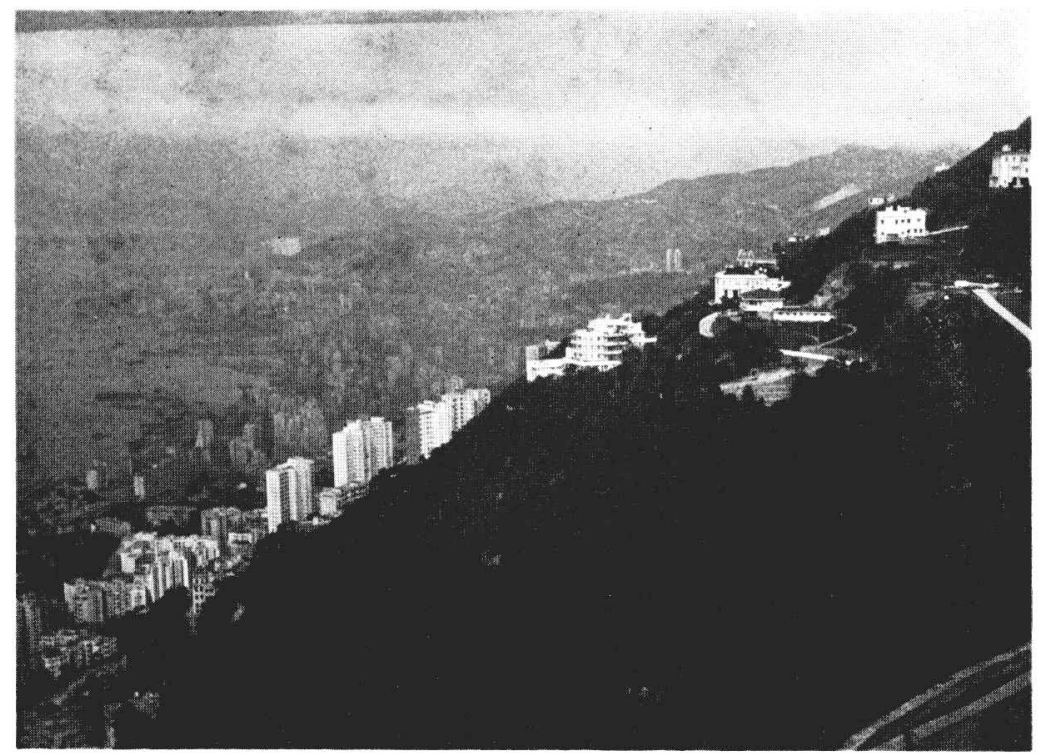

写真 1. ホンコン島の斜面の高級アパートと北角の商業地区 


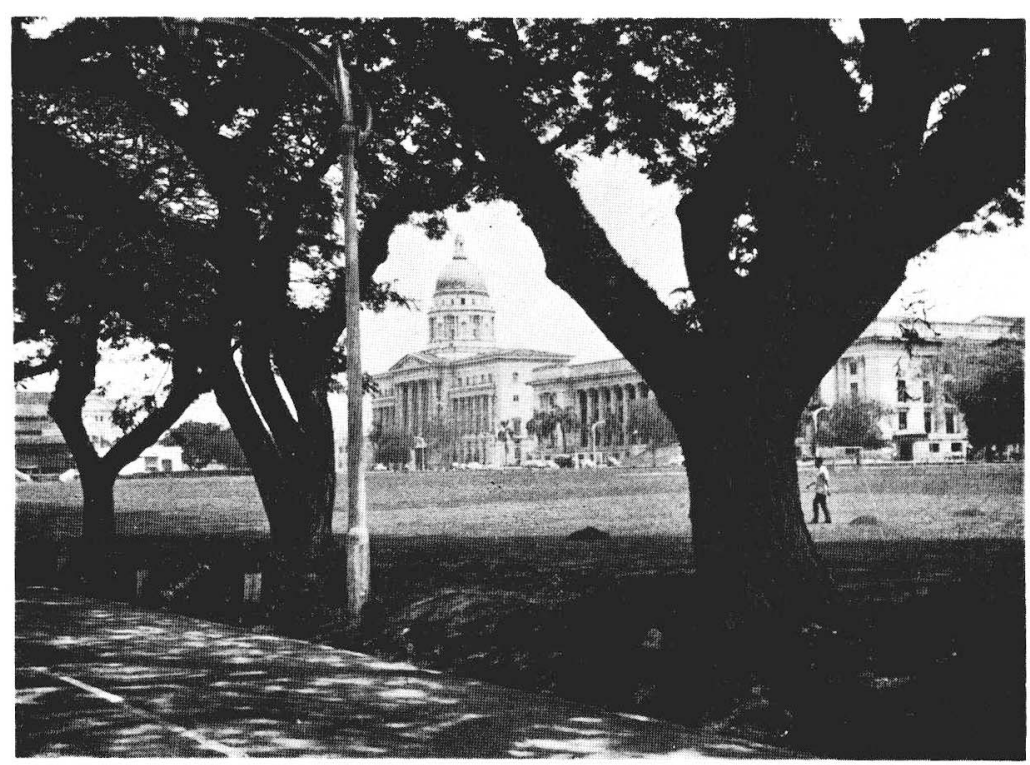

写真 2. シンガポールの政庁付近

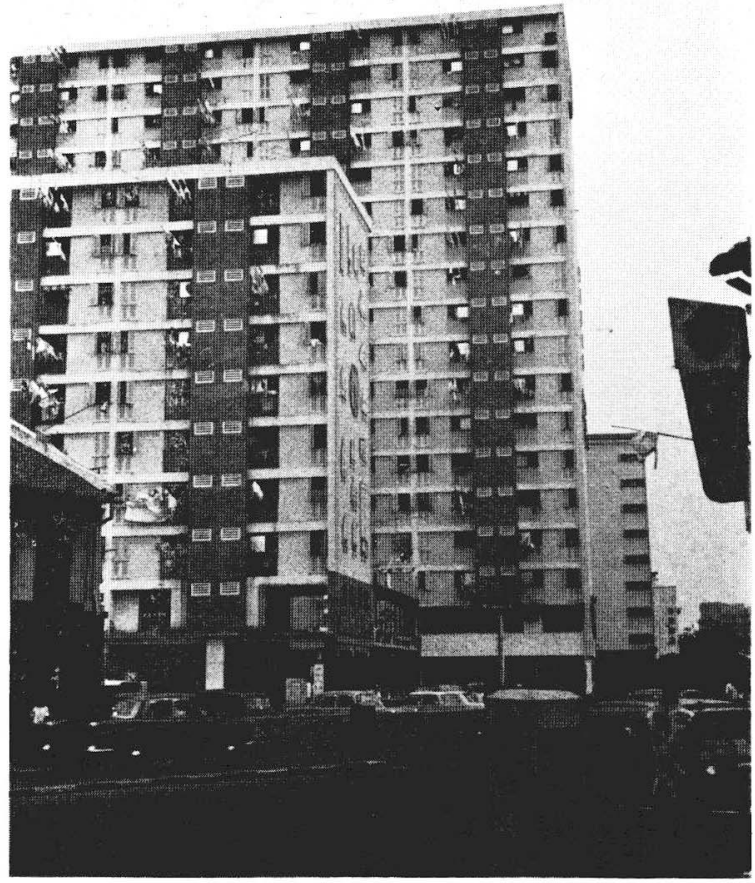

写真 3. シンガポールの市街地の改造（セレギー地区） 


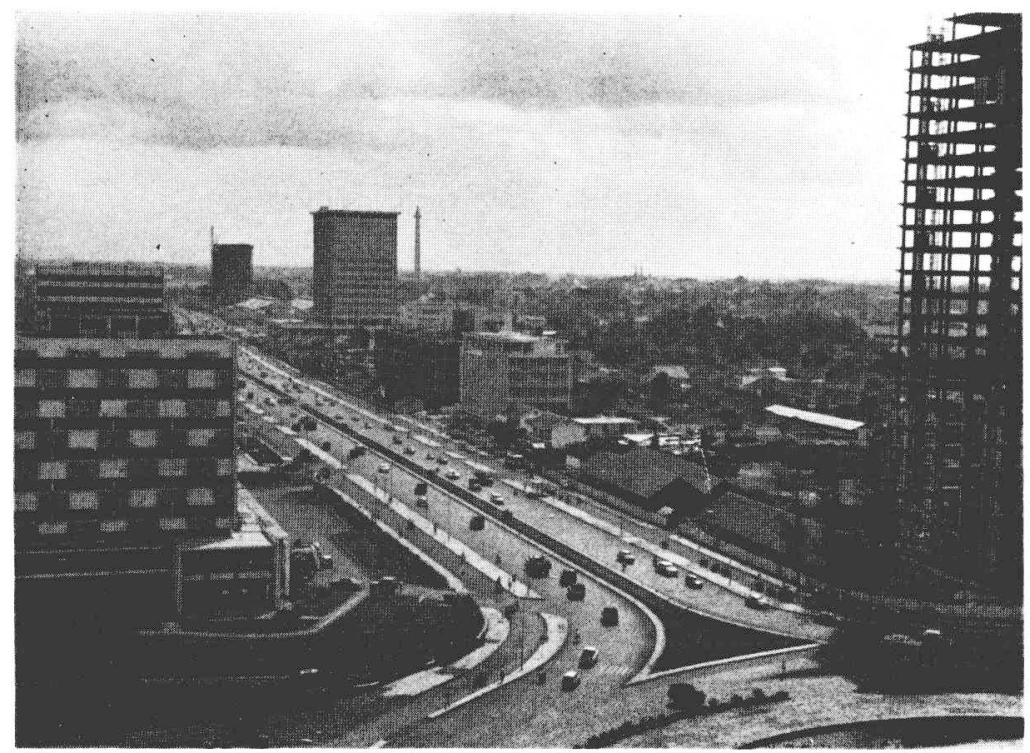

写.真 4. ジャカルタの新しい事務所地区

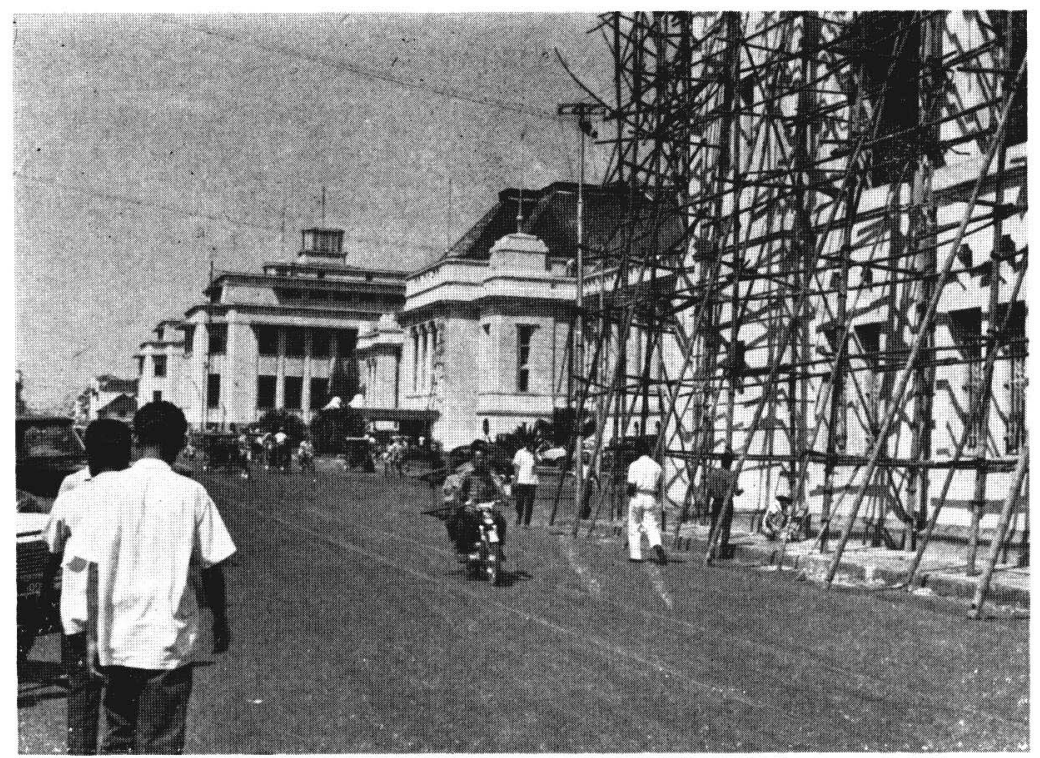

写袁5.シュカルタの古い銀行街

\section{Preliminary Report on the Areal Structure of 5 Metropolises in South-east Asia}

\section{Ken-ichi TANABE}

The author visited Hong Kong, 3angkok, Singapore, Djakarta and Calcutta in April to June, 1967, for the study of urban structure and urbanization. Although these cities have different historical backgrounds respectively, they have some general character in common concerning the structure of functional areas.

1. Central area is in an administrative area where there are some old-fashioned buildings of European style, and is adjacent to a central park. 


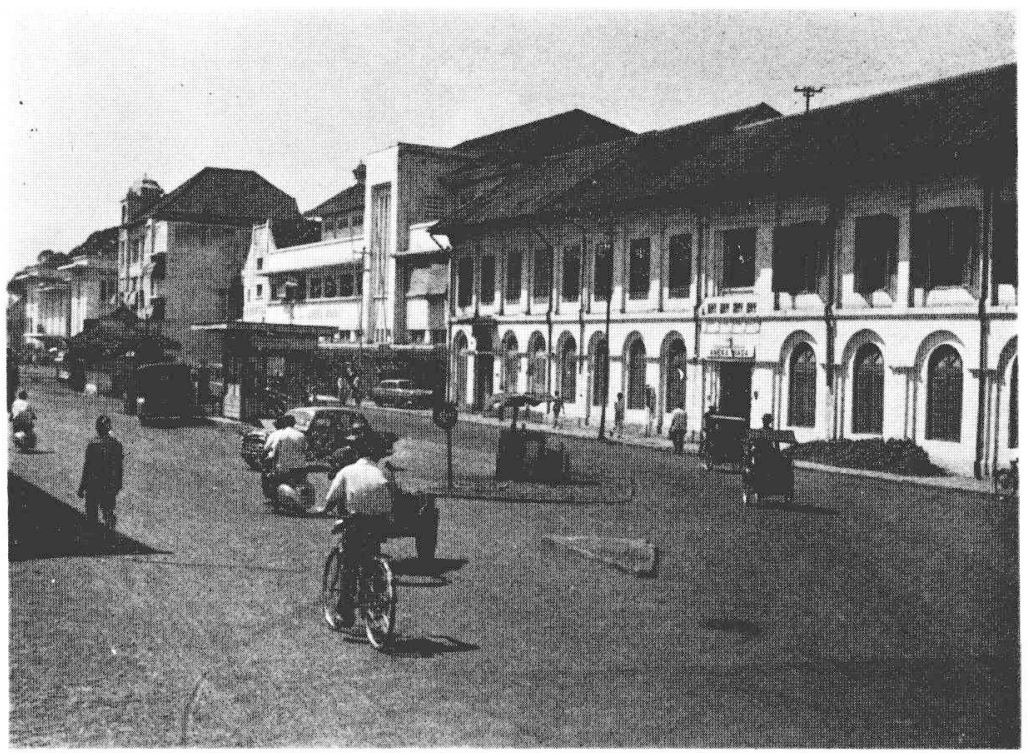

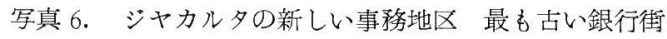

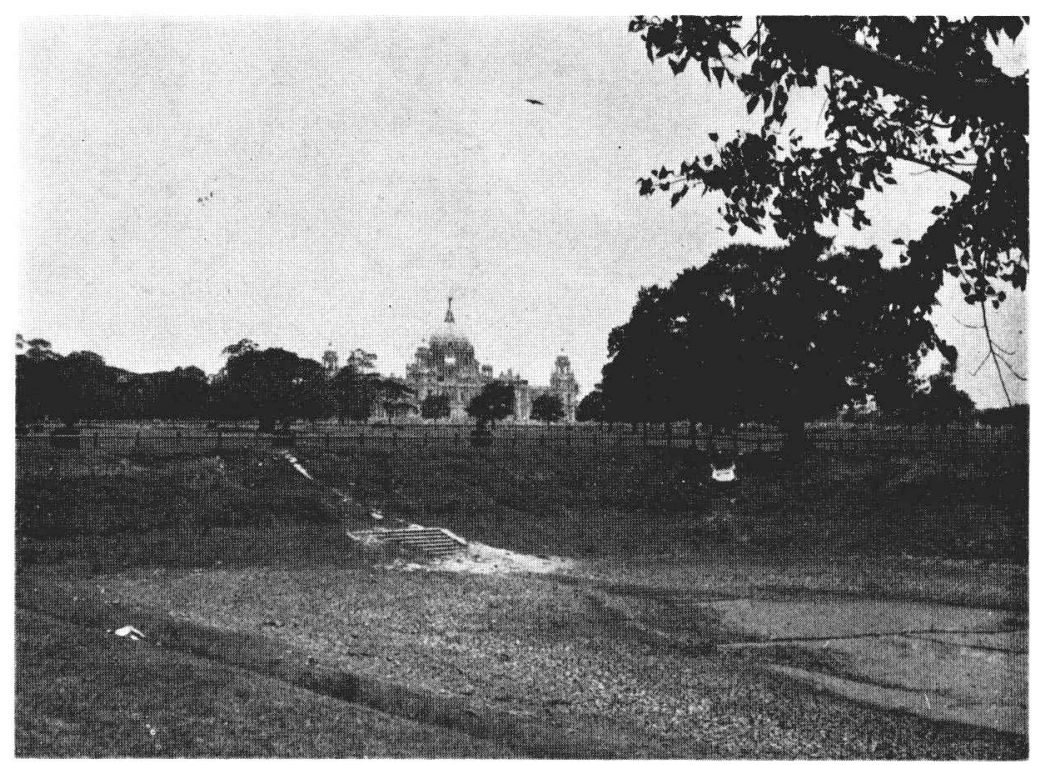

写真 7. カルカッタの中央公園

2. Central business area and commercial area are in Chinese district (so-called China town) neighbouring to the former administrative area. Commercial area is divided into wholesale and shopping districts.

3. Chinese district has both commercial and residential functions, so the development of areas specialized for residence is limited. Such areas were built in the colonical age, and some new residential areas were added to the outskirts of the former residential areas. 